\title{
Effects of soak-time and spatial heterogeneity on sampling populations of spanner crabs Ranina ranina
}

\author{
Steven J. Kennelly \\ Fisheries Research Institute, NSW Agriculture \& Fisheries, PO Box 21, Cronulla, NSW 2230, Australia
}

\begin{abstract}
A series of field experiments was done in spanner crab Ranina ranina (Linnaeus) fishing grounds to determine the effects on catch per unit effort (CPUE) of crabs due to soak-time and the species spatial heterogeneity. Standard and optimally-designed baited tangle-traps were used in a nested experimental design to catch crabs on gear set in place for various periods of time. To determine the degree of spatial and short-term temporal variability in CPUE, replicate sets of traps were set at different locations, depths and times of day. Cost-benefit analyses of this experiment yielded optimal numbers of traps and sets of traps to be used at each location and depth in subsequent sampling. The minimum time one should leave traps in the fishing grounds to achieve maximal CPUE was determined as $60 \mathrm{~min}$. Different locations and depths yielded quite different CPUE's indicating that future surveys should encompass several locations and depths. Time of day had no significant effects on CPUE. Costbenefit analyses showed that 5 traps on each of 3 sets should be used at each location and depth to optimize CPUE given the limited time availabe to survey a given place. The consequences of this replication on the sizes of standard errors in future sampling were estimated. A uniform and optimal methodology is developed from the results discussed in this and a previous paper which will be used in subsequent censussing of this species' distributions and abundances. Finally I discuss the worth of manipulative experimentation to test specific hypotheses about species which are sampled using baited traps and note the value of cost-benefit analyses of pilot studies in designing surveys of such species' populations.
\end{abstract}

\section{INTRODUCTION}

Fisheries research involving the sampling of populations often employs catch per unit of effort data (CPUE) to estimate relative abundances and age/size structures of exploited populations. This requires accurate estimates of both catch and effort (Collie \& Sissenwine 1983; for review see Sissenwine 1984). Although data on catch are relatively simple to obtain as counts and measurements of caught animals, the effort involved in obtaining given catches is often more difficult to quantify and standardize. Ideally, methods should be uniform, unbiased, optimal with respect to the quantity of catch obtained, and replicated in space and time so as to allow reliable estimates of relative abundances and size structures of target species. The focus of many previous studies has been the reliability and accuracy of methods that sample abundances of commerciallyimportant marine species (Larkins 1963, 1964, Jester 1973, Hamley 1975, Kjelson \& Colby 1977, Fogarty \& Borden 1980; see review by Sissenwine et al. 1983).
There have also been several papers which have assessed baited trapping techniques as a means of estimating relative abundances of exploited populations of large decapods (Thomas 1953, Sinoda \& Kobayasi 1969, Miller 1978, 1979, 1981, 1983). These papers point out several factors that may influence such CPUE data apart from the absolute abundances of crabs and lobsters. These factors include the shape of traps, the net used in traps, the bait used, competition between traps, the soak-time of traps (length of time traps are available to animals), and the position of fishing effort in space and time. An earlier paper (Kennelly \& Craig 1989) considered the first 4 of these factors in developing a sampling unit which could be used in subsequent sampling of the relative abundances of populations of spanner crabs Ranina ranina (Linnaeus) off the east coast of Australia. In the present paper I consider the last 2 of these factors by describing experiments which determine the best deployment of the sampling tool in large-scale, long-term surveys of $R$. ranina distributions and abundances. These experiments involved assess- 
ing effects on the sampling regime due to different soak-times and inherent spatial and temporal variability in the species distributions.

Ranina ranina are large marine brachyurans found throughout the Indo-Pacific region (Barnard 1950). They are found in coastal waters in depths of 10 to $80 \mathrm{~m}$ on sandy substrata in which they bury (Skinner \& Hill 1987). Populations of $R$. ranina have been exploited commercially in Hawaii, Japan, the Philippines and recently, the east coast of Australia (Skinner \& Hill 1986). There have been, however, only a few studies concerning the biology and ecology of this valuable species (Onizuka 1972, Fielding \& Haley 1976, Tahil 1983, Brown 1986, Skinner \& Hill 1986, 1987) and so many of the most basic aspects of its biology are unknown, including its distributions, abundances and rates of growth. A first step in obtaining this information is to develop a sampling methodology which can be used in future surveys of populations of this species.

There are several reasons why the CPUE of crabs in baited traps may asymptote with increasing soaktimes, e.g. fading bait odour, saturation of traps with caught crabs, loss of bait by being eaten, and the capture of all available crabs, and such effects have been examined in many fisheries (e.g. Sinoda \& Kobayasi 1969, Munroe 1974, Fogarty \& Borden 1980, Powles \& Barans 1980). In the present study I compare the CPUE of Ranina ranina on baited traps left for various periods to determine the period which maximizes catches of individuals.

Spatial heterogeneity in the distributions and abundances of target species directly influences estimates of CPUE and therefore measures of relative abundances. To account for such variability, it is necessary to replicate one's sampling strategy such that it provides the most reliable and representative results unter the logistic restrictions of limited time and/or money. The

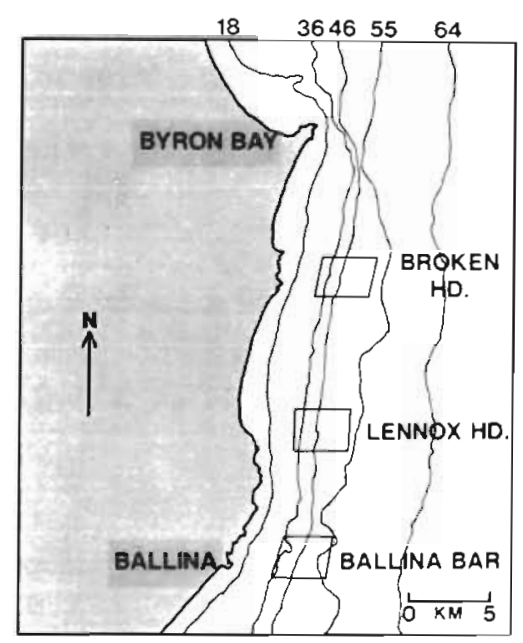

Fig. 1. Locations of study sites. Depth contours are in metres choice of optimal numbers of replicates can be easily calculated using well-established cost-benefit analyses of data from pilot surveys (Snedecor \& Cochran 1967. Winer 1971, Saila et al. 1976. Underwood 1981). These techniques have been successfully used in a variety of habitats from desert and terrestrial plains (Robinette et al. 1974, Caughley et al. 1976) to kelp forests and coral reefs (Kennelly \& Underwood 1984, 1985, Fowler 1987). Here I present cost-benefit and variance analyses on data from a pilot survey of distributions and abundances of Ranina ranina which provide the optimal degree of spatial replication and replication throughout the day which may be used in subsequent surveys.

\section{MATERIALS AND METHODS}

This study was done off the north coast of New South Wales, Australia, in the same fishing grounds as those used by commercial fishermen. To obtain CPUE data, we used modifications of commercial fishing methods. Traps were square frames $1.2 \times 1.2 \mathrm{~m}$ and made of mild steel with $85 \mathrm{~mm}, 4$-ply net doubly hung over each frame with a standard $230 \mathrm{~mm}$ drop. This type of trap catches the most crabs and the widest size-range of crabs (Kennelly \& Craig 1989). One bait (fish-skeleton) was placed in the middle of each trap. Five traps were set out $60 \mathrm{~m}$ apart along a trot-line placed cross-current on the substratum in the area or depth to be sampled $160 \mathrm{~m}$ is the distance at which neighbouring traps are independent; Kennelly \& Craig 1989). These sets of traps were left for given soak-times during which individual Ranina ranina were attracted to the bait and became entangled on the net before reaching the bait. When traps were hauled, crabs were disentangled, counted, measured (eye-orbit to carapace length), sexed and returned to the sea.

Expt 1 - Effects on CPUE due to soak-time. Four replicate sets with 5 traps on each were set randomly off Lennox Head, NSW (28 $47^{\prime}$ S; $153^{\circ} 39^{\prime} \mathrm{E}$ ) (Fig. 1) for periods of 15, 60 and $120 \mathrm{~min}$. Sets of traps were placed so that returned crabs could not subsequently be caught on traps left for longer periods.

Expt 2 (pilot survey) - Efiects on CPUE due to different times of day, depths and locations. Three replicate sets with 5 traps on each were set out at each of 2 depths (40 and $60 \mathrm{~m}$ ), in the morning and afternoon off Broken Head $\left(28^{\circ} 43^{\prime} \mathrm{S} ; 153^{\circ} 39^{\prime} \mathrm{E}\right)$, Lennox Head $\left(28^{\circ}\right.$ $\left.48^{\prime} \mathrm{S}_{i} 153^{\circ} 38^{\prime} \mathrm{E}\right)$ and Ballina Bar $\left(28^{\circ} 53^{\prime} \mathrm{S}_{i} 153^{\circ} 37^{\prime} \mathrm{E}\right)$ (Fig 1). A minimum soak-time of 60 min was used as this was the optimal soak-time found from Expt 1.

Analyses of data. Data frorn both experiments were treated in a similar way to that outlined in Kennelly \& Craig (1989). For each trap, I calculated the percentage of crabs caught in each of the following size-classes: 
males: $\leq 79,80-89,90-99,100-109,110-119$ and $\geqslant 120 \mathrm{~mm} ;$ females: $\leqslant 69, \quad 70-79, \quad 80-89,90-99$, $100-109$ and $\geqslant 110 \mathrm{~mm}$. I also calculated the percentage of crabs that were male and $\geqslant 93 \mathrm{~mm}$ (i.e. crabs usually retained by fisherman for sale), the total number of crabs caught on each trap and the mean size of each sex caught on each trap.

Each of these 16 sets of data for each experiment was tested for homogeneity of variances (Cochran's test) and analysed in the relevant 2 -factor analysis of variance (Expt 1) or 4-factor analysis of variance (Expt 2). Sets of data with heterogeneous variances were transformed using arc-sine or natural logarithms and reanalysed. Means were compared using Ryan's tests. Those sets of data (either transformed or untransformed) which satisfied Cochran's test and which showed significant effects in the analyses of variance and Ryan's tests are presented below.

To determine optimal numbers of sets and traps for sampling Ranina ranina at any period and location, costbenefit analyses were done for 14 sets of data from Expt 2 (sets of data concerning mean sizes of crabs were not used). The standard cost-benefit procedure was followed (e.g. Snedecor \& Cochran 1967, Winer 1971, Underwood 1981, for similar treatments of these analyses see Kennelly \& Underwood 1984, 1985). The product of 2 sums was minimized to determine the optimal number of sets and traps in these analyses with 2 levels of replication (replicate sets at any location/ depth and replicate traps within each set). These sums are the total cost of each sampling period and the variance of the estimated mean of each sampling period.

The restricting cost in this study is the amount of time available during the basic sampling period at sea. The total time available to sample one depth at one location is $2 \mathrm{~h}$. The time taken to manoeuvre between sets (i.e. set out and retrieve) is $20 \mathrm{~min}$, and the time taken to clear and sample one trap is 4 min $30 \mathrm{~s}$. The variance for estimated means in any experimental design may be determined from the appropriate means square in the analysis of variance, by methods discussed by Winer (1971) and Underwood (1981).

\section{RESULTS}

\section{Expt 1}

Of all sets of data analysed in this experiment, only the total number of crabs showed any significant effects due to soak-time (analysis of variance; $p<0.05$; Table 1). Significantly more crabs were caught after $60 \mathrm{~min}$ and $120 \mathrm{~min}$ than after $15 \mathrm{~min}$ (Fig. 2). There was no significant difference between traps left for 60 and 120 min.

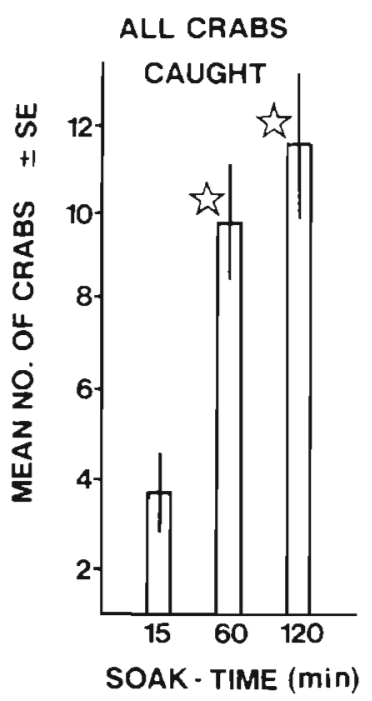

Fig. 2. Ranina ranina. Effect on CPUE of numbers due to different soak-times $(n=20)$. In this and subsequent figures, $\checkmark$ indicates a significant difference among means (Ryan's test, $p<0.05$ )

Table 1. Ranina ranina. Summary of 2 -factor analysis of variance to determine the effect of different soak-times on CPUE of spanner crabs. In this and subsequent tables, ns: non-significant $(p>0.05), \cdots$ significant $(p<0.01)$, " significant $(p<0.05)$

\begin{tabular}{lcc|}
\hline Treatment & df & Total no. of crabs \\
\hline Soak-time & 2 & $\cdots$ \\
Sets & 9 &. \\
Residual & 48 & \\
Ryan's test: 15 min $<60$ min $=120$ min (see Fig. 2) \\
All other sets of data showed no significant effects due to \\
soak-time
\end{tabular}

\section{Expt 2}

The total number of crabs caught varied among places and depths (significant interaction in analysis of variance $p<0.05$; Table 2). Significantly more crabs were caught off Broken Head in shallow water than anywhere else (Fig. 3A). There was no effect of fishing at different times of the day (analysis of variance; $p>0.05$ ). There was no significant effect for the percentage of retainable crabs, except that none were caught in deep water early in the day off Lennox Head (Fig. 3B).

There were proportionately more large males (>120 mm) caught off Ballina Bar than all other places (Fig. 4A). Proportionately more medium-sized males $(90-99 \mathrm{~mm})$ were caught off Broken Head in shallow water early in the day than anywhere else (Fig. 4B). The only other significant effect was for small female crabs $(70-79 \mathrm{~mm})$ where there were proportionately more in deep water off Broken Head, both early and late in the day (Fig, 4C). 


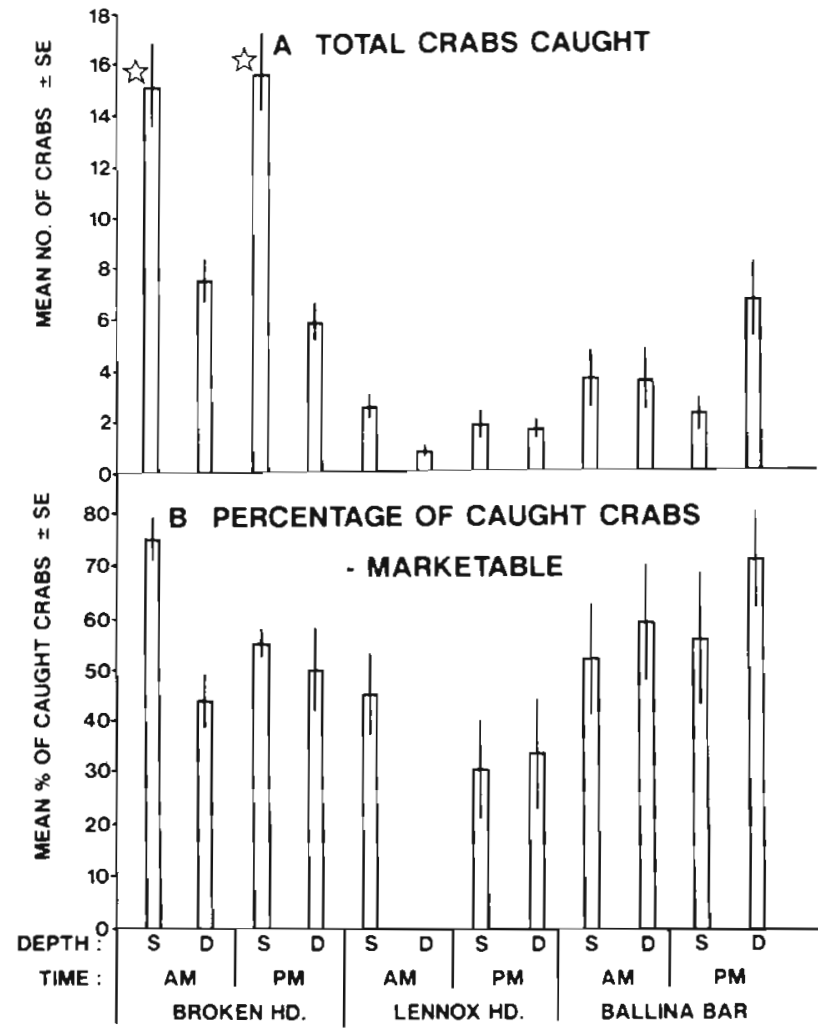

Fig. 3. Ranina ranina. Effects on CPUE of (A) total numbers of crabs and $(B)$ percentage of retainable crabs, due to depth, time of day and in different locations $(n=15)$ given in Table 3. Sampling an experiment several times would reduce these standard errors.

\section{DISCUSSION}

The results reported here permit the development of techniques for sampling populations of Ranina ranina that are optimal with respect to soak-time and the species' spatial heterogeneity and catchability throughout the day.

Traps left for short periods (15 min) caught far fewer crabs than those left for 60 and 120 min. Further, there were no detectable differences in catches between traps set for 60 and $120 \mathrm{~min}$, indicating that after 60 min, traps caught as many crabs as they were likely to in that place at that time. Because the tangle-net method of capture precludes escape of tangled crabs, a soak-time of $60 \mathrm{~min}$ is sufficient for the capture of those crabs able to be caught in this experiment. In applying this result to other places and times, one must assume that the results obtained here are applicable to other populations of spanner crabs. Whilst it would be ideal to repeat this experiment at other places and times, this is impractical and I must conclude from these, the only available data, that a uniform soak-time of 60 min is sufficient for subsequent sampling. The lack of signifi-

Table 2. Ranina ranina. Summaries of 4 -factor analyses of variance to determine effects on CPUE of spanner crabs due to fishing in different places $(P)$, at different times of the day $(T)$ and in different depths (D)

\begin{tabular}{|c|c|c|c|c|c|c|c|c|}
\hline Treatment & $\mathrm{df}$ & $\begin{array}{l}\text { Total no. } \\
\text { of crabs }\end{array}$ & $\begin{array}{c}\% \text { of retained } \\
\text { crabs }\end{array}$ & $\begin{array}{l}\% \text { of females } \\
70-79 \mathrm{~mm}\end{array}$ & $\begin{array}{l}\% \text { of males } \\
>120 \mathrm{~mm}\end{array}$ & $\begin{array}{l}\% \text { of males } \\
110-119 \mathrm{~mm}\end{array}$ & $\begin{array}{l}\% \text { of males } \\
100-109 \mathrm{~mm}\end{array}$ & $\begin{array}{l}\% \text { of males } \\
90-99 \mathrm{~mm}\end{array}$ \\
\hline Place & 2 & $\cdots$ & $\cdots$ & $\cdots$ & $\cdots$ & $\cdot$ & $\cdots$ & $\cdots$ \\
\hline A.m. vs p.m. & 1 & ns & ns & ns & ns & ns & ns & $\cdots$ \\
\hline Depth & 1 & ns & ns & ns & ns & ns & ns & ns \\
\hline Sets & 24 & $\cdots$ & ns & ns & $\mathrm{ns}$ & ns & ns & $\mathrm{ns}$ \\
\hline$P \times T$ & 2 & ns & ns & ns & ns & $\mathrm{ns}$ & ns & ns \\
\hline$P \times D$ & 2 & $\cdot$ & $\cdot$ & $\cdots$ & ns & ns & $\cdots$ & $\cdot$ \\
\hline $\mathrm{T} \times \mathrm{D}$ & 1 & ns & ns & ns & $n s$ & $\cdot$ & ns & ns \\
\hline$P \times D \times T$ & 2 & ns & ns & ns & ns & ns & ns & ns \\
\hline Residual & 142 & & & & & & & \\
\hline
\end{tabular}

\section{Cost-benefit analyses to determine optimal numbers of sets and traps per set}

The optimal numbers of replicate traps and numbers of replicate sets to be sampled at any place are summarized in Table 3. Having determined the appropriate numbers of replicate sets and traps, the standard error for the mean of data in any sample period may be estimated as the square root of the variance calculated from the variance equation. The anticipated sizes of standard errors for sampling an experiment once are cant effects due to soak-time on the proportions of different sizes and sexes of Ranina ranina indicates that different sizes and sexes of this species travel to, and are entangled on, traps at similar rates.

Results from Expt 2 indicate a marked degree of spatial heterogeneity in abundances of Ranina ranina. Total numbers of crabs caught, percentages of retainable crabs, large and medium-sized males, and small females varied among localities ca $9 \mathrm{~km}$ apart (Figs. 3 and 4). There were also substantial differences in the CPUE of crabs at different depths. One must conclude, 


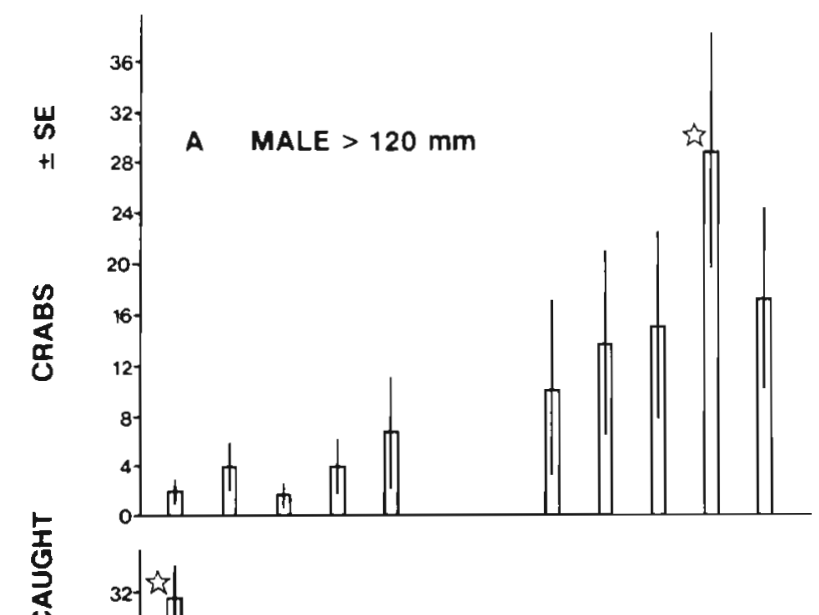

B MALE $90 \cdot 99 \mathrm{~mm}$
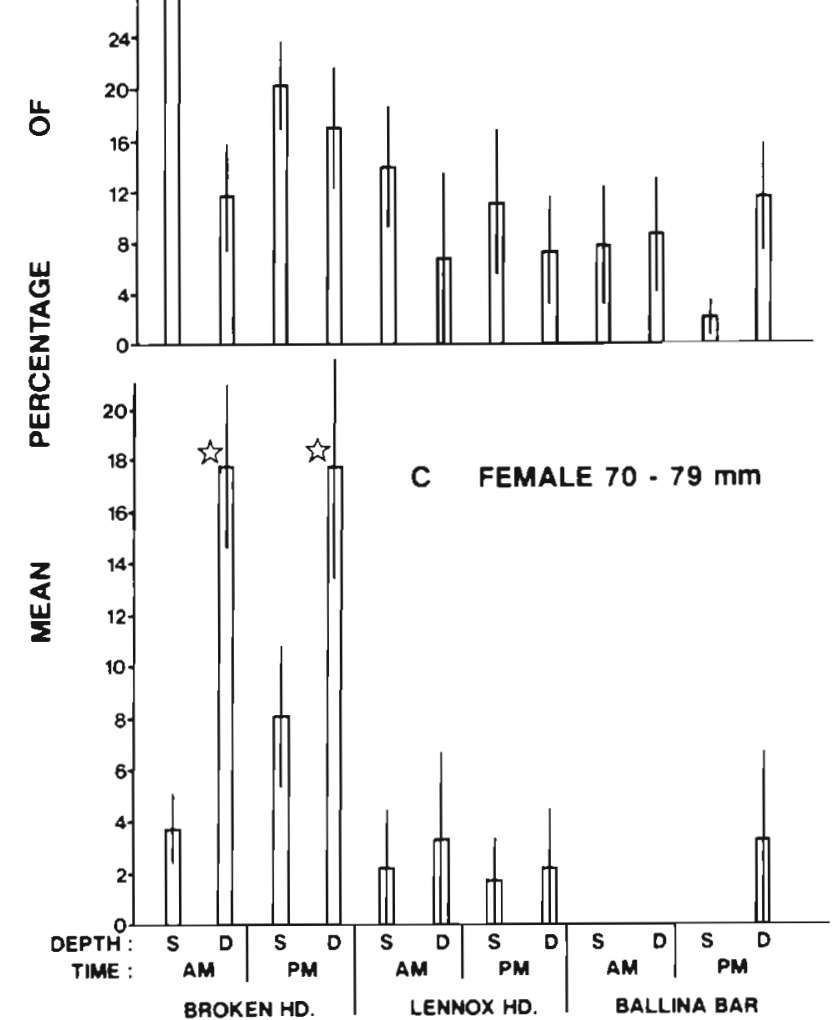

Fig. 4. Ranina ranina. Effects on CPUE of (A) percentage of male crabs $\geqslant 120 \mathrm{~mm}$, (B) percentage of male crabs $90-99 \mathrm{~mm}$ and (C) percentage of female crabs $70-79 \mathrm{~mm}$ due to depth, time of day and in different locations $(n=15)$

therefore, that any future monitoring of populations should be conducted at several sites and several depths. The time of sampling during daylight hours was not important: there were no consistent differences in catch rates of various sizes and sexes of crabs between morning and afternoon samples.

To properly conduct sampling at any location and depth, one must use suitable replication of sets of traps and traps per set. The cost-benefit analyses of data from Expt 2 showed that to best sample the total numbers of crabs at a given location and depth requires 5 traps on each of 3 sets (Table 3). This yields an estimated standard error of $24.3 \%$ of the mean for one census. To best sample individual size-classes of different sexes requires greater replication: e.g. the optimal replication required to maximize the proportion of the catch that is retainable is 2 sets of 13 traps. This shows that the proportion of retainable crabs varies among individual traps greater than it varies between sets. If I was concerned with censussing only the commercial catch, this level of replication would be used. Because I am concerned with surveying whole populations of Ranina ranina, however, I need to employ that replication suggested from total catches: 3 sets of 5 traps. The consequences of this replication on estimates of the standard errors associated with various size-classes and sexes of crabs is included in Table 3. Whilst most standard errors using this replication are quite large, it is the maximum allowable replication given the time available for sampling and, in any case, these standard errors would decrease as many sample periods are included in a long-term survey.

The field experiments described in this paper and in Kennelly \& Craig (1989) have led to the development of a methodology which can be used to most accurately quantify the distributions and relative abundances of Ranina ranina in their fishing grounds off the coast of New South Wales. This method involves the use of 5 replicate traps made of flat steel and covered by a double layer of $85 \mathrm{~mm}$, 4-ply net, set at distances of $60 \mathrm{~m}$ apart long a trot-line. Three such sets of traps should be used at each depth in each location in the particular survey under examination. The kind of bait and the time of day that sampling occurs is of small consequence, but traps should be left in place for a minimum of $60 \mathrm{~min}$. In this fashion, the benefits from one's sampling effort in terms of catch rates of $R$. ranina will be maximized, and the best possible picture of this species' distributions and abundances can be derived. Further, these methods will also permit continued monitoring of populations of $R$. ranina following the implementation of future management strategies.

In this paper (and Kennelly \& Craig 1989) manipulative experiments assessed most of the sources of error incurred when estimating the relative abundances of organisms using CPUE from baited traps. Such information allowed the development of optimal methods for obtaining estimates of relative abundances. Thomas (1953) and Miller (1983) note that this sort of information is a pre-requisite for any meaningful large-scale monitoring of populations of such species. The work presented here also illustrates the worth of pilot surveys in providing a priori estimates of the spatial and temporal heterogeneity inherent in the distributions of 
Table 3. Summary of cost-benefit analyses of data from Expt 2

\begin{tabular}{|c|c|c|c|c|c|c|c|c|c|c|c|}
\hline & $\begin{array}{l}\text { Total no. } \\
\text { of crabs }\end{array}$ & $\begin{array}{l}\% \text { of } \\
\text { retained } \\
\text { crabs }\end{array}$ & $\begin{array}{c}\% \text { of } \\
\text { females } \\
100-109 \\
\text { mm }\end{array}$ & $\begin{array}{c}\% \text { of } \\
\text { females } \\
90-99 \\
\text { mm }\end{array}$ & $\begin{array}{c}\% \text { of } \\
\text { females } \\
80-89 \\
\text { mm }\end{array}$ & $\begin{array}{c}\text { of } \\
\text { females } \\
70-79 \\
\mathrm{~mm}\end{array}$ & $\begin{array}{c}\% \text { of } \\
\text { males } \\
>120 \\
\mathrm{~mm}\end{array}$ & $\begin{array}{c}\% \text { of } \\
\text { males } \\
110-119 \\
\mathrm{~mm}\end{array}$ & $\begin{array}{c}\% \text { of } \\
\text { males } \\
100-109 \\
\mathrm{~mm}\end{array}$ & $\begin{array}{c}\% \text { of } \\
\text { males } \\
90-99 \\
\mathrm{~mm}\end{array}$ & $\begin{array}{c}\% \text { of } \\
\text { males } \\
80-89 \\
\text { mm }\end{array}$ \\
\hline Variance among sets & 3.04 & -31.1 & -10.4 & -31.5 & 58.8 & -2.4 & -9.8 & 0.1 & -15.3 & 3.4 & 8.6 \\
\hline Variance among traps & 11.8 & 1095.7 & 205.9 & 484.3 & 205.2 & 88.7 & 410.9 & 192.5 & 632.9 & 280.1 & 220.7 \\
\hline Optimal no. of sets & 3 & 2 & 2 & 2 & 4 & 2 & 2 & 1 & 2 & 1 & 2 \\
\hline Optimal no. of traps & 5 & 13 & 10 & 9 & 4 & 13 & 14 & 79 & 14 & 20 & 11 \\
\hline Mean in pilot expt & 5.5 & 47.8 & 3.1 & 9.5 & 7.6 & 5.0 & 8.6 & 8.1 & 22.1 & 12.2 & 5.7 \\
\hline Estimated SE (\%) & 24.3 & 10.8 & 72.6 & 35 & 68.8 & 29.8 & 36.5 & 19.8 & 17.5 & 34.1 & 66.4 \\
\hline $\begin{array}{l}\text { Estimated SE using } 3 \text { sets } \\
\text { of } 5 \text { traps }(\%)\end{array}$ & 24.3 & 16.6 & 103 & 49 & 75.6 & 45.5 & 57.4 & 44.2 & 27.5 & 36.4 & 73.6 \\
\hline
\end{tabular}

species. Such estimates allow the design of sampling regimes which estimate relative abundances and distributions in the most cost-effective and accurate way.

Acknowledgements. This study was funded by a Fishing Industry Research Trust grant. I sincerely thank J. Lavis for the use of his vessel, his expertise and for many helpful discussions. I also thank $\mathrm{J}$. Craig for assistance with all aspects of the field work. W. Gum and P. Kennelly lended additional field assistance. I finally thank Drs K. McGuinness, W. Fletcher, J. Bell, R. Keamey and Mr C. Gray for critically reading the manuscript.

\section{LITERATURE CITED}

Barnard, K. H. (1950). Descriptive catalogue of South African decapod crustacea. Ann. S. Afr. Mus. 38: 396-399

Brown, I. W. (1986). Population biology of the spanner crab in south-east Queensland. Fishing Industry Project 81/71 final report

Caughley, G., Sinclair, R., Scott-Kemmis, D. (1976). Experiments in aerial survey. J. Wildl. Mgmt 40: 290-300

Collie, J. S., Sissenwine, M. P. (1983). Estimating population size from relative abundance data measured with error. Can. J. Fish. Aquat. Sci. 40: 1871-1879

Fielding, A., Haley, S. R. (1976). Sex ratio, size at reproductive maturity and reproduction of the Hawaiian kona crab Ranina ranina (Linnaeus) (Brachyura, Gymnopleura, Raninidae). Pacif. Sci. 30: 131-145

Fogarty, M. J., Borden, D. V D. (1980). Effects of trap venting on gear selectivity in the inshore Rhode Is. American lobster Homarus americanus Fishery. Fish. Bull. U.S. 77 : 925-933

Fowler, A. J. (1987). The development of sampling strategies for population studies of coral reef fishes. A case study. Coral Reefs 6: 49-58

Hamley, J. M. (1975). Review of gillnet selectivity. J. Fish. Res. Bd Can. 22: 1943-1969

Jester, D. B. (1973). Variations in catchability of fishes with color of gillnets. Trans. Am. Fish. Soc. 102: 109-115

Kennelly, S. J. Craig, J. R. (1989). Effects of trap design, independence of traps and bait-type on sampling populations of spanner crabs Ranina ranina. Mar. Ecol. Prog. Ser. $51: 49-56$

Kennelly, S. J., Underwood, A. J. (1984). Underwater microscopic sampling of a sublittoral kelp communty. J. exp. mar. Biol. Ecol. 76: 67-78
Kennelly, S. J., Underwood, A. J. (1985). Sampling of small invertebrates on natural hard substrata in a sublittoral kelp forest. J. exp. mar. Biol. Ecol. 89: 55-67

Kjelson, M. A., Colby, D. R. (1977). The evaluation and use of gear efficiencies in the estimation of estuarine fish abundance. In: Wiley, M. (ed.) Estuarine processes, Vol 2. Academic Press, New York, p. 416-424

Larkins, H. A. (1963). Comparison of salmon catches in monofilament and multifilament gillnet. Commerc. Fish. Rev. 25: $1-11$

Larkins, H. A. (1964). Comparison of salmon catches in monofilament and multifilament gillnets - Part II. Commerc. Fish. Rev. 26: 1-7

Miller, R. J. (1978). Entry of Cancer productus to baited traps. J. Cons. int. Explor. Mer. 38: 220-225

Miller, R. J. (1979). Saturation of crab traps: reduced entry and escapement. J. Cons int. Explor. Mer. 38: 338-345

Miller, R. J. (1981). Design criteria for crab traps. J Cons. int. Explor. Mer. 39: 140-147

Miller, R. J. (1983). Considerations for conducting field experiments with baited traps. Fisheries 8: 14-17

Munroe, J. L. (1974). The mode of operation of Antillean fish traps and the relationships between ingress escapement, catch and soak. J. Cons. int. Explor. Mer. 35: $337-350$

Onizuka, E. W. (1972). Management and development investigations of the kona crab, Ranina ranina (Linnaeus). Div. Fish \& Game, Dept. Land \& Nat. Res. Report, Honolulu, Hawail

Powles, H., Barans, C. A., (1980). Groundfish monitoring in sponge-coral areas off the south-eastern United States. Mar. Fish. Rev. 42: 21-35

Robinette, W. L., Loveless, C. M., Jones, D. A. (1974). Field test of strip census methods. J. Wildl. Mgmt 38: 81-96

Saila, S. B., Pikanowski, R. A., Vaughan, D. S. (1976). Optimum allocation strategies for sampling benthos in the New York Bight. Estuar. coast. mar Sci. 4: 119-1.28

Sinoda, M., Kobayasi, $T$ (1969). Studies on the fishery of Zuwai crab in the Japan Sea - VI. Efficiency of the Toyama Kago (a kind of crab trap) in capturing the Benl-zuwal crab. Bull. Jap. Soc. scient. Fish. 35: 948-956

Sissenwine, M. P. (1984). The uncertain environment of fishery scientists and managers. Mar Res. Econ. 1: 1-30

Sissenwine, M. P., Azarovitz, T., Suomala, J. B. (1983). Determination of fish abundance. In: Macdonald, A. G. Priede, I. G. (eds.) Experimental biology at sea. Academic Press, New York, p. 51-101

Skinner, D. G., Hill, B. J. (1986). Catch rate and emergence of male and female spanner crabs (Ranina ranina) in Australia. Mar. Biol. 91 461-465 
Skinner, D. G., Hill. B. J. (1987). Feeding and reproductive behaviour and their effect on catchability of the spanner crab Ranina ranina. Mar. Biol. 93: 211-218

Snedecor, G. W., Cochran, W. G. (1967). Statistical methods, 6th edn. Iowa State University Press, Iowa

Tahil, A. S. (1983). Reproductive period and exploitation of the red frog crab, Ranina ranina (Linnaeus 1758) in Central Tawi-Tawi, Philippines. Philipp. Scient. 20: 57-72

This article was presented by Dr A. J. Underwood, Sydney, Australia
Thomas, H. J. (1953). The efficiency of fishing methods employed in the capture of lobsters and crabs. J. Cons. int. Explor. Mer. 18: 333-350

Underwood, A. J. (1981). Techniques of analysis of variance in experimental marine biology and ecology. Oceanogr mar. biol. A. Rev. 19:513-605

Winer, B. J. (1971). Statistical principles in experimental design, 2nd edn. McGraw-Hill Kogakusha Ltd, Tokyo

Manuscript first received: July 12, 1988

Revised version accepted: April 17, 1989 